\title{
Power and Marginality in the Poetry of Nol Alembong and
}

\section{Emmanuel Fru Doh}

\author{
Dr. Andrew T. Ngeh ${ }^{1 *}$ \\ ${ }^{1}$ Department of English, Faculty of Arts, University of Buea, Cameroon \\ *Dr. Andrew T. Ngeh, E-mail: ngehandrew@yahoo.com
}

Received: September 12, 2016 Accepted: September 18, 2016 Online Published: September 23, 2016 doi:10.22158/wjssr.v3n4p463 URL: http://dx.doi.org/10.22158/wjssr.v3n4p463

\begin{abstract}
The political history of Anglophones in Cameroon in determining their evolution and growth as a people and community has been bedeviled by intrigues, fraud, manipulations, betrayals, double standards, abuse of power and the marginalization of Anglophones. Given the numerical disadvantage of the Anglophones who constitute only one fifth of Cameroon's population, the Francophones who are in the majority use the political power they possess to oppress, subjugate and repress the Anglophones. The fundamental question that is raised in this article is: for what reason is power acquired in contemporary African politics? Against this backdrop, the poetic orientation of Anglophone Cameroonian poets sprouts from the close scrutiny and consideration of the past and present socio-political, historical, cultural and economic landscape.

Guided by the new historicist critical theory and the socialist realism of the Lukacsian and Leninist-Marxist paradigm in analyzing and evaluating Nol Alembong's Forest Echoes (2012) and Emmanuel Fru Doh's Not Yet Damascus (2007), this paper argues that the poetic works of Alembong and Doh are a response to the social isolation, economic exploitation and political marginalisation of Anglophones in Cameroon. The paper proposes and recommends the culture of dialogue in order to express a response to life and create a harmonious society where peace is maintained and sustained and tension is defused.
\end{abstract}

\section{Keywords}

power, marginality, dialogue

\section{Introduction}

Nol Alembong and Emmanuel Fru Doh are Anglophone Cameroonian poets who both comment on and participate in the on-going socio-political change in Cameroon. In Forest Echoes and Not Yet Damascus written respectively by Alembong and Doh, the poets demonstrate their social commitments to the fight against social injustice and neocolonialism. The poems in the two collections are a searing critique of an aberrant society bereft of social justice and hope. 
African politicians, who have been entrusted the responsibility of being servants to their people, have betrayed this critical assignment. No sooner had they assumed power than they stepped into the shoes of the colonial rulers. During the struggle for independence, the African politician and the masses were in one camp against the "common enemy": the white man. But upon assuming power, they betrayed the indigenous trust given to them by the masses. The nation's wealth is considered as their personal property. Seen from this perspective, the reaction of the masses has always been violent. The two poets, by virtue of their position in society, belong to the intelligentsia but they strongly identify with the oppressed in the society because an art that is functional must be politically active on the side of the oppressed. And because the ruling class exercises coercive force on the ruled which is violent in nature, the reaction of the oppressed is somewhat violent since violence begets violence.

In postcolonial discourse, the centre is the place from which power, be it political, military, economic, social, religious or ethical emanates. There is always a second level of it; the exercising of this power which could result in marginality, oppression, subjugation and repression. In Cameroon like elsewhere in Africa, power is not acquired for the amelioration of the human condition; rather, power is acquired to enrich those who wield such powers. This is exactly what is obtained in the Cameroonian political setting. The asymmetrical power equation is responsible for the socio-political and economic problems in Cameroon as will be demonstrated in some of the poems analyzed in the paragraphs that follow below.

\section{The Genesis of the Problem}

The territory called Southern Cameroon joined French East Cameroon in 1961 in a Plebiscite organized by the United Nations Organization. French Cameroon acquired independence from France in 1960 with the name "La Republique du Cameroun". The British Southern Cameroons, instead of just granting independence to the territory, the United Nations, with the complicity of the United Kingdom, the administering authority, proposed two options to the peoples of the Southern and Northern Cameroons in the February 11, 1961 Plebiscite it organized:

1) Do you wish to achieve independence by joining the already independent Federal Republic of Nigeria? OR

2) Do you wish to achieve independence by joining the already independent Republic of Cameroun? In the Plebiscite, Southern Cameroons voted overwhelmingly (70.49\%) to achieve independence by joining la Republique du Cameroun, while the Northern Cameroons voted to achieve independence by joining the already independent federal Republic of Nigeria. Southern Cameroon joined La Republique to form the Federal Republic of Cameroon.

Recently, declassified information have now revealed that the United Kingdom was opposed to separate independence for the Cameroons under United kingdom tutelage because Her Majesty's government which based its decision on the 1959 Phillipson Report that southern Cameroons was not 
economically viable as a separate entity, feared that if the United Kingdom accepted separate independence for the southern Cameroons, the territory would have to depend on subsidy from the British treasury to run its affairs (Elad et al., 1995).

In the Referendum of 1972 Cameroon was transformed from a Federal state to a United Republic of Cameroon. That was when the term "Anglophone" gained currency in Cameroon's history books. In 1984, Paul Biya who had taken over from Amadou Ahidjo in 1982 in a Presidential decree changed the country from a united republic to only a republic being the initial name of French East Cameroon. This radical transformation was perceived by Anglophone Cameroonians as a complete annexation and assimilation of the Anglophones in Cameroon. There is a consensus amongst Anglophone Cameroonian intellectuals that this move by the First Republic rendered the Anglophones voiceless. This is the genesis of the Anglophone marginalization in Cameroon. Hilarious N. Ambe in Change Aesthetics in Anglophone Cameroon Drama and Theatre sums up the predicament of Anglophones in Cameroon in these words:

In post independence Cameroon, in terms of infrastructure and appointments to top ranking positions in administration and government, Anglophones, compared to their input and resources, are very marginally compensated. A recent presidential decree of ministerial appointments in Cameroon, Number 2002/217 of August 2002, signals a devastating mockery of the extent of Anglophone marginalization in Cameroon. In the decree there are only eight Anglophone ministers out of a total of fifty-three. Again, in this cabinet of fifty-three, there are thirty with portfolios: only two of the eight Anglophone ministers have portfolios (2007, p. 8).

Alembong and Doh's poetic orientation and consciousness are a response to this abuse of power that results in the oppression, marginalization and repression of Anglophone Cameroonians. These poets also write with the conviction that if poetry cannot change their society, the utilization of provocative poetic diction and images can shock the reader and give nightmares to the leadership in Cameroon. Hence, one of their tasks is to help Anglophone Cameroonians regain their dignity, voice and to know what they have lost in both human and material terms.

Fundamentally, power, marginality and dialogue are three important concepts that undergird the appreciation and comprehension of this article; consequently, their definitions are important. This is in keeping with Bernard Fonlon's submission in "The Idea of Literature" that the first principle of any scientific discourse is the definition of one's terms or concepts so as to know "clearly and precisely right from the start" what these terms or concepts mean (1982, p. 179).

According to Nanda S. and Warms R. L. in Cultural Anthropology, power "is the ability to make and carry out decisions affecting one's own life, control the behavior of other human beings, and transform objects and resources" (p. 226). Sandstrom L. Kent in Symbols, Selves and Social Reality adds that "power is the capacity to get other people to think, feel, or act this way" (p. 140). Finally, Buckley W. in Sociology and Modern Systems Theory defines power as "control or influence over the actions of 
others to promote other's goals without their consent, against their will, or without their knowledge or understanding" (p. 186). Buckley's definition falls squarely within the context of this article because the dominant francophone elite who wield both political and economic power use it for their own selfish ends.

Those who possess less power like the Anglophones in Cameroon are considered to be on the margin of socio-political affairs since they are not in the mainstream of power. Graham Furniss and Liz Gunner in Power, Marginality and African Oral Literature define marginality as the "differential positions between social categories, for example, men and women or between the old and the young, and to social distance from a seat of constituted power within a particular society" (p. xii). Consequently, the term marginality exists with unequal power relations and constitutes one of the basic features of asymmetrical relationships. It is this asymmetrical relationship that exists between the numerically advantaged Francophone Cameroonians and the numerically disadvantaged Anglophone Cameroonians that has brought about crisis in Cameroon.

\section{Aim and Objectives of the Study}

This paper sets out to demonstrate the effects of power abuse as depicted by Alembong and Doh in their poetry, and how this conflict created by power abuse can be resolved through the culture of dialogue. Alembong and Doh in their poetic vision use their poetry as a response to the socio-political, historical and cultural realities overwhelming the Cameroonian society. Their poetic vision expresses and demonstrates the voicelessness of Anglophones in Cameroon and how they can be empowered by giving a voice. Consequently, one of the contentions of this article is that the poetry of Alembong and Doh can be considered as a veritable instrument that can be used to resolve conflict in the Cameroonian society by dismantling the asymmetrical equation of power. Secondly, the poets in their poetics proffer alternative and different social institutions from the dictatorial and autocratic ones established by the ruling class to democratic ones where everyone has a role to play in nation building. The ultimate objective of this study is to ascertain the view that culture, including literature, reproduces the class structure of society that highlights the equal distribution of the common wealth and power in opposition to industrial and financial capitalism where human values are debased.

\section{Statement of the Problem}

From the conceptualization of the various terms, the problematic this study sets out to address emerges. Given their numerical disadvantage, the Anglophones in Cameroon are socially isolated, politically marginalized and economically exploited. All these only accentuate the voicelessness of the minority Anglophone Cameroonians. The poetics of Alembong and Doh is a response to the socio-political, cultural and economic realities that overwhelm the Cameroonian society as the Anglophones are excluded from the mainstream of almost all spheres of life. From the problem as stated, the following 
questions provide the searchlight for this paper:

1) What is the essence of the acquisition of power in contemporary African politics?

2) What is the relationship between power and good governance?

3) What is the role of dialogue in an asymmetrical power relation?

4) What is the role of poetry of conscientisation in an unjust political setting?

\section{Hypothesis}

In view of the problem and questions as stated above, this article sets out to demonstrate that the poetic orientation of Alembong and Doh is a response to the misuse of power by the dominant francophone elite in Cameroon which has resulted in the marginalization and voicelessness of the Anglophones in Cameroon. This segment of the Cameroonian society is politically marginalized, socially isolated and economically exploited. Thus, the poetic orientation and vision of these poets extend to matters like the equal appropriation of social space in an asymmetrical power dispensation.

\section{Theoretical Framework}

The critical theories that have been employed in the evaluation of the poetry of the two poets are New Historicism and the aesthetics of socialist realism. Considering the symbiotic and dialectical relationship that exists between power and marginality in the Cameroonian society, new historicism is relevant here because "new historicism is the textuality of history and the historicity of the text" (Louis Montrose, as quoted in Peter Barry, 1995, p. 172). Furthermore, the revolutionary nature of Doh and Alembong's poetic diction calls for the utilization of socialist realism/Marxist critical paradigm because it is only through a Marxist conceptualization of a society that genuine justice can be attained.

The new historicist critical theory gained currency in the literary academia in the 1980s as a counter discourse to the American text-based approach known as New Criticism. Critics of New Criticism gave an intrinsic analysis of literature, thereby, treating a literary text as an autonomous self-sufficient entity quite separate from society, history or any external causal agent. The new historicists, however, take the contrary view and contend that literature is the product of a particular socio-historical and cultural context and should therefore be interpreted against the background of its context. New historicism insists on the parallel reading of literary and non-literary texts usually of the same historical period. Hence, the interpretation of a text can only be meaningful and relevant when the historical circumstances under which the text was created are taken into consideration. Proponents of this approach to criticism include Laurence Lerner, Jerome McGann, Irving Howe, Paul Ricoeur, Stephen Greenblatt and Catherine Gallagher.

In summation, the co-relation between literature and history, in the area of New Historicism, is a reciprocal relationship. This approach connotes that it is not only history that influences literature; the reverse can also be true. This explains why Murfin and Ray (1979, pp. 239-240) state: "New Historicist 
critics assume that works of literature both influence and are influenced by historical reality, and they share a belief in referentiality, that is a belief that literature both refers and is referred to by things outside itself". The above contention demonstrates that literature can also shape the face/phase of history. This means that literature can (re) shape and (re) direct history and vice versa.

\section{The Aesthetics of Socialist Realism}

The concept of socialist realism marks an important advance in the development of Marxist aesthetics on literature and art in general. Socialist realism according to http://www.l.evengenvaertcentre.be/ is a Soviet artistic doctrine, realistic in its nature which has a purpose the furtherance of the goals of socialism and communism. Basically, some of the features of socialist realism include: optimism and hope, conscientisation and revolt. Chidi Amuta in The Theory of African Literature outlines the following characteristic features of socialist realism. He contends, “...the essential attributes of socialist realist expression include (a) the use of simple and accessible language, (b) a sympathetic portrayal of characters from the oppressed, (c) a sense of patriotism defined in terms of concern with the struggle of socialism" (p. 140). Socialist realist writers must be politically active on the side of the oppressed and this is the position Alembong and Doh have taken.

Maxim Gorky, the doyen of socialist realism summarizes these socialist realist features thus:

“...it is clear that in addition to the necessity of studying the language and developing the ability to select the simplest, most graphic and colourful words from a literary language, which while perfected to a high degree is nevertheless littered with empty and ugly words, the writer must also have a good knowledge of the past history and of the social phenomenon of contemporary society in which he is called upon to fulfill his dual role of midwife and grave-digger" (pp. 32-33). Thus socialist realism and new historicism close ranks here because new historicism also emphasizes the relevance of history in any literary discourse.

Finally, Es'kia Mphahlele contends that African writers especially critics must always "hammer their theories out of their socialist realism" (p. 84). To him, amongst other things, socialist realism comprises the following:

“...the continuous dialogue between the present and the living traditions that first inspired the negritude movement; the imperatives of our modern existence and those we have inherited from our ancestors; the colonial oppression... the violence, poverty, the nagging antithesis between capitalism and socialism... this dialogue will certainly determine in time the direction of literature" (p. 84).

Anglophone Cameroonian poets like Nol Alembong, Bate Besong, Mathew Takwi, Gahlia Gwangwa'a and Emmanuel Doh have been influenced by the Marxist ideology and the historical happenings in their society as will be demonstrated in the analysis that follows. It is for these reasons that these particular critical theories were chosen for this article. Both the historical and environmental realities have contributed immensely in shaping and directing the authorial ideology and social vision in the 
poetry of these two poets. Furthermore, the poets that emerged in Cameroon in the 1990s were empowered by the socialist ideology especially so because of the wind of change that blew across Eastern Europe when Gorbachev was grappling to maintain the disintegration of Soviet Union. That event helped to strengthen the radical and revolutionary aesthetics in their poetry.

The concepts of power, marginality and dialogue are reflected in the following poems "Double Decade" and "In Moments like these" by Doh, and "Tug of War" and "The Sin of Glory" by Alembong.

\section{Textual Analysis}

In "Double Decade" Doh recounts the mystery that surrounds the Lake Nyos gas disaster of 21 of August 1986 in Cameroon. It also establishes and contextualizes the suspicious and hypocritical roles the government officials in Cameroon and international bodies played. This particular poem is a historical statement on the people's plight and predicament after this disaster. The poet takes the reader down memory lane: from the lake Nyos gas disaster that claimed more than two thousand lives on 21 of August 1986 to the economic hardship and the sacrifices the wretched masses have to make for the nation to move forward. This poem is Doh's attempt to give to the yet scientifically inexplicable Lake Nyos toxic gas explosion of August 1986, which killed at least two thousand people and several herds of cattle in the villages of Nyos, Subum, Fang and Chah in Menchum Division in the North West Region of Cameroon. More significantly, the poem is not merely an attempt at offering a hypothetical input into that catastrophe; it explores the other components that continued to despise the harmonious growth and evolution of people. One of these components is the myth that surrounds this disaster, which the poet explores and exploits. When the lake exploded in 1986, many reasons were advanced. The government advanced as her argument that the explosion was caused by accumulated gas in the lake. The opposition contradicted the government by saying that it was a bomb that the Israelites tested in Cameroon. One of Anglophone Cameroonian playwrights, Bole Butake dramatizes in one of his plays titled Lake God (1986) as the failure of the traditional authority to perform certain cultural rites at the lake to avert an impending disaster. Even, in the play, some white men were spotted at the lake before its explosion, and Butake does not state their mission there. Today in Cameroon, Cameroonians are yet to unravel the mystery and myth that surrounds such an unfortunate catastrophe. "Double Decade", is therefore, a response to this historical reality. It indicates a past event that has a continuing effect on the socio-political reality of the nation. Two world views in this poem are dialectically related; first, the government claimed that it was a natural disaster, but the poet representing the people makes a dangerous insinuation that it was man-made. The government has not done anything in memory of those who lost their lives in this disaster. The poet makes the point that neocolonialism is being sustained by carnage, brutal repression and reckless exploitation. The poetic persona is embittered with this political sclerosis as he bemoans: 
Gentle the years have rolled by

Since the Nyoseous bubble-Pharaoh's lie-

And a thousand guinea-pigs and more!

Two decadent decades already,

And all the aid rushed in by giants,

"Concerned giants"

Yet two decades after

And post all the ado'

Nothing!

Nothing told the nation

Of meaning and causes

Of the Lake God's wrath (Doh, p. 3).

A poem contains both a semantic and aesthetic meaning, and to understand it is to appreciate both. That is why the poet uses a series of poetic devices to enhance his ideological posture. He uses the biblical metaphor of "Pharaoh", to communicate his point of view about the President: "Since the Nyoseous bubble-Pharaoh's lie". Pharaoh is a dense symbol with metaphoric possibilities; he stands for oppression, marginalisation and repression. In biblical history, the Israelites suffered untold miseries in the hands of the Pharaohs of Egypt. In this poem Doh adjusts, changes, adapts and brings out the experiences of the oppressed masses by relating them to the enlightened intellectual climate with the New Testament's gravity on contemporary African societies as he considers and orders the world to give purpose and justification to the lives of the oppressed. The problem has always been how to avoid the bleakness of a purely scientific materialist view of the world with its lack of values, spirit, and purpose and to avoid the confining repressive orthodoxies of most religious and their otherworldliness at the expense of this, probably the only life we have. Thus, by drawing from this biblical quarry, Doh situates this particular poem within the context of "Promised Land" poetry.

The Cameroonian predicament is thus compared to the Israelites in the hands of the Pharaohs. "Since the Nyoseous Bubble-Pharaoh's lie-" because when the lake exploded the government claimed that it was the accumulation of gas in the lake. Another school of thought, which the poet subscribes to, states, that it was a bomb that was tested by western imperialists on Cameroonian soil. The Pharaoh metaphor and its association with miseries, frustration, death and suffering are demonstrated in this poem. "Double Decade" is not a simple figment of the poet's imagination but emerges from a historical background with which the poet is still in touch. The Pharaoh metaphor and its parallel in the title of the collection, Not Yet Damascus, indicate the darkness of the fallen spirit in contrast to those who live by spiritual illumination after Saul's conversion to Paul on his way to Damascus (Acts of the Apostles, $9: 4)$.

Evident in the poem is the word Nyoseous, which is the poet's coinage. It depicts the sad incident that 
happened in Nyos in Wum, in the North West Region of Cameroon in 1986. Because Doh wants the intelligentsia and the masses to understand the point he is making, his language is devoid of erudition, simple but evocative and full of ironic undertones. The poetic critique also extends to matters of hypocrisy and double-standards of the government. For example, when he wants to bring out the hypocritical roles of the government and western imperialists in this crisis, he describes the western imperialists as "concerned giants" when popular opinion at the time was that these very western imperialists used Cameroon as a testing ground for one of their weapons of mass destruction. The poet/persona states; "Those victims of man's labs/Yet we learn not the meaninglessness of life" (p. 3). Cameroonians have become specimen in the laboratories of western imperialists: "Since the Nyoseous bubble-Pharaoh's-lie/And a thousand guinea-pigs and more!" (p. 3). The victims of this unfortunate disaster are metaphorically described as "guinea-pigs".

The poet identifies with the Cameroonian people and victims of the Lake Nyos disaster as he constantly refers to this people as "my people": "The nation is yet to mourn for my people" (p. 3). The claim that poetry can dissolve and resolve conflict in its art is rather a different ideological and aesthetic argument that other theory about art that perceives art as creating conflicts. One of the contentions of this paper is that poetry can resolve conflicts through the principles of dialogue.

According to the poet/persona, the government is also guilty of this national tragedy for two reasons: Two decadent decades already/The nation is yet to mourn for my people/No national monument to remind us of them/Or giving meaning to their sacrifice (p. 3). Secondly, government officials made capital gains out of this natural/artificial disaster: "And so I remember/The stolen aid by those in charge/And the victims of the victims/Left to rot in state-sponsored misery" (p. 3). The poetic voice believes that the absence of hope is a clear indication of defeat. Thus the refusal to succumb to despair is couched in a tone that bespeaks anger, impatience and a firm determination to resist the oppressors. The poet states: "Let me see you bribe Yahweh/For twenty more wasteful years" (p. 3). Since the ruler cannot cheat nature, it follows that one day he will die as he cannot bribe God. The poet's tone in these two lines shows his anger and his resolve to actively engage the enemy alongside the masses. There is a plaintive cry of lamentation for the victims of the brutal system, not a sense of pity but a refusal to accept subjugation and domination by those who control political power. Even the title of this collection, Not Yet Damascus is very apt. Coincidentally, Paul Biya is the name of Cameroon's serving President who has been at the helm of power for close to thirty-four years now. The title suggests that Paul Biya should be Saul Biya since he has not yet reached Damascus. This means Cameroonians are still under his persecution and oppression: no peace, no liberty and no justice. Secondly, today's Damascus, the capital of Syria is war torn, reflecting the socio-political sclerosis in Cameroon. By relating the predicament of Cameroonians to that of Syria, the poet places his poetry within the context of "Promised Land Poetry".

These alliterations, "double decade" and "...decadent decades" emphasize the misery and frustration 
the Cameroonian people have been in the hands of a President who has officially and unofficially declared himself life-president. Since the President is yet to reach Damascus, Cameroonians will know no peace as they still remain under his persecution. The poet/persona bemoans:

Left to rot in state-sponsored misery

Yet how close we are

In Hades these victims to join,

And see them still clinging

On to golden nothingness

And worthless money boxes

Those victims of man's labs

Yet we learn not the meaninglessness of life... (p. 3).

The alliteration "decadent decade" is repeated twice in the poem. The effect of this repetition is to create an image of the Cameroonian people who are naïve, unsophisticated and docile because for this "decadent decade" they could not rise up in protest. Thus the people can hardly say anything about the lies-telling and arbitrariness of the ruler.

Finally, the diction used by the poet expresses brutality, frustration, death, dearth, sterility, meaninglessness and nothingness. Words and phrases like "a thousand guinea-pigs", "decadent decade", "idiotic nimbleness", "victims", “orangutans", "state-owned misery", "nothingness", "worthless money" and "meaninglessness of life" paint and create a frightful atmosphere in the mind of the reader and emphasize the fact that the leadership in Cameroon has not yet reached Damascus. The poem is a quest for wisdom, salvation, national independence and a sort of Promised Land poetry since most African countries are yet to attain genuine independence.

The biblical allusion in this poem is significant in the sense that it brings out the global dimension Christianity is assuming in Africa and other continents in the world. In Africa, for example, Christianity that was perceived as a twin brother to colonialism is now pivotal in some African literary texts. For instance, John Ngong Kum Ngong's collection of poems entitled Snatched from the Grave (2010) and Mathew Takwi's Messing Manners (2014) articulate this point. This dialectic in cultural beliefs and practices that dominated literary discourses in the 1950s, 1960s, 1970s and 1980s have gradually led to a dialogue of culture, and this clearly finds expression in the poetic collections mentioned above.

Like Doh, Alembong's ideological orientation and consciousness in "Tug of War", is a powerful expression of hope and faith in the efficacy of the liberation struggle. In this poem, the poet brings out the dialectical relationship that exists between the ruling class and the ruled. Both parties take very rigid positions in defense of their interests. In this dramatic poetic piece, Alembong's focus is on the many voices that express societal concerns. He allows both the rulers and the ruled express their worries freely, actually placing them on the same plane:

Government: You are a plague of rats 
That ruins the nation the way

Rats sack a barn of grain.

Your "ghost towns" crusade has

Made the nation a colony of rats

In church ceilings.

Heed the call of Zacchaeus:

Pay your taxes, so we may stay in business.

People: You are the crocodile

That swallows its own eggs.

The honey bee is wise:

It sucks nectar but

Leaves back pollen on the flower,

Our wages run for months unpaid

Because you're the crocodile, not the bee.

Pay us, so we may pay our taxes (p. 32).

It is clear from this particular poem that change involves a dialectical relationship between destruction and construction of the status quo: destruction of the old order and the building of a new system. The poem is an eloquent expression and assertion of the will of the Cameroonian people to achieve their dreams. The government does not want to pay its workers and yet expects them to pay taxes. This poem represents an advanced or regressive development in the economic basis. There are two issues at stake which are related to economic determinism; that is the link between ideological superstructure and economic base. This two-stanza poem is charged with hateful emotions for both the oppressors and the oppressed. None of them is willing to give in. The startling revelation of the people is interesting in the sense that the truth will always shock those who have lived their lives in lies-telling. These rigid positions are defined by the social consciousness of each which is determined by their world-views.

In terms of linguistic expression, there is neither complicated stylization nor artificial adornments. That explains why his flora and fauna are drawn from his immediate cultural environment. His diction attests to this. For instance, words like: flowers, rats, bee, nectar and crocodile are some of the words that show that Alembong was inspired by his cultural environment.

Deeper in thought, closely argued and rich in metaphors and symbols, "Tug of War" is an expression of the asymmetrical mode of existence between the very powerful of the society and the oppressed. The poet's sense of patriotism finds expression through the archetypal animal imagery/metaphor he explores to convey his ideology. He makes effective use of animal imagery to reinforce his thematic concerns. The masses are described as "a plague of rats/That ruins the nation the way/Rats sack a barn of grain". And the government attributes this to the ghost town of 1992 after the flawed Presidential elections. The people on the other hand insist that they be paid before they can pay their taxes. The 
government is perceived as "...the crocodile/That swallows its own eggs". Antithetical to that of the government, the stand of the people is a declaration of intent: an explicit confirmation of the necessity to confront neocolonialism and challenge the bourgeoisie ideology that has compromised their very existence.

The title of the poem "Tug of War" is incorporated into the poem itself, which creates a feeling of being in the midst of the action as the two classes seem to engage in an actual tug of war. The theme of life as change and the sub-theme or motif as of the continuity of a continually changing social reality is attested in the different world-views expressed in the poem. The conciseness of the images and the anger in his tone highlight the disappointments of the political systems put in place in the Cameroonian society. Each party uses grotesque animal images to describe the other. While the masses are rats, the government is a crocodile that swallows its own eggs; the latter is a frightful symbol that depicts the degenerative process and the lack of continuity in the Cameroonian socio-economic life. Alembong's poetry is rooted in his studies in the oral traditions of his people. This explains why he utilizes such images in his poetry. For instance words like: flowers, rats bees, nectar and crocodile are some of the words that show that Alembong was inspired by his cultural environment. When he was interviewed in 2010 by this researcher, the poet admitted that his poetry, from the standpoint of style, is influenced by his studies in Oral Literature in the sense of simplicity and accessibility. The poet/Alembong contends:

"[...] from the point of view of style, yes my poetry is in line with the mainstream African poetry. And also you must have realized that my style is influenced by my studies in oral traditions. So there is a lot of orality that comes in when you look at my style" (Interviewed on 8 February, 2010).

From the reading of the two poems above, it is clear that they are densely argued, well thought out, and very engaged with socio-political and cultural experiences. There are also indications of unusual nightmarish descriptions of the experiences of the masses. The two poems question both natural and socio-political tragedies within the framework that is informed by class consciousness and dialectical world-view. The two poets believe that one of the contributing factors that has led to the postcolonial tension and conflict in the Cameroonian/African societies is the tendency among those who find themselves in positions of power to see those positions as their birthright.

Doh and Alembong equally perceive the conscientisation of the oppressed as an integral weapon of raising awareness in their society for their eventual liberation.

\section{Conscientisation and Critical Consciousness}

The term conscientisation is derived from the Portuguese word; "conscientizacao", which means learning to perceive social, political and economic contradictions and to take action against the oppressive elements of reality (Paulo, 1970, p. 17). Freire argues that the raising of social consciousness can lead to social discontent and even anarchy. "Critical consciousness...is anarchic. Others add that critical consciousness may lead to disorder" (1970, p. 17). 
According to the Nigerian author, Femi Osofisan, "man can change his society if the right decisions are made. There is no reason why we should not be able to move our society from its present chaos. And this is one of the fundamental duties of literature" (Takem, 1990, p. 174). Since Doh and Alembong are concerned about change for the interest of the masses and the working class, their poetry becomes instructive. Poetry becomes a viable means of effecting the necessary critical awareness in the consciousness of the audience of the socio-economic and political malaise overwhelming their society. The primary virtue of literature is its subversive change hidden behind the façade of entertainment. The concept of conscientisation, which leads to the raising of social consciousness, finds both ideological and aesthetic expression in the following two poems by Doh: "In Moments Like These" and "Like Serpents". These two poems focus on the treacherous and the hypocritical roles of the ruling class in the management of socio-political affairs. In "In Moments Like These", the poet brings out the failure of leadership in contemporary African society where life is meaningless and useless because of the eccentricity, recklessness and irresponsibility of the leaders. Cameroon has become, "The desert of life" and not even the oasis of life. Cameroon is often described as Africa in miniature because of its bilingual status. For Doh what is happening in Cameroon's body politic is what is happening in most African countries. The poet identifies with the people and decries the breach of the implicit social contract between the government and the populace. The union is an unholy and doubtful one. hear the poetic voice: "For government, leaders, then the self/When my soles tread to an unholy union/Worth the soul of doubt/Then melting away in this mighty quicksand" (p. 2). In opposition to this breach of the social contract by the leaders, Doh proffers an alternative means of survival as he exhorts the oppressed to resist the repression of the ruling class. Even though he uses the "I" persona, it should be seen as the collective "we" because the poet in this poem identifies with the oppressed: "I will grapple and grapple/Keeping the faith, albeit/Frail, even as I resist/Like a candle wick" (p. 2).

In the above poem, Doh calls on the oppressed to rebel against injustice, repression, marginalization and oppression. He proposes dialogue as a panacea to the socio-political and economic ailment overwhelming the Cameroonian society. Again, Doh's patriotic sentiments and his strong attachment to the cause of the marginalized and the dregs of the society find expression in poems such as "Like Serpents", a political statement on the callousness and the unpredictability of Cameroonian contemporary rulers. In describing the leaders, the poet uses a serpentine image to convey his ideological posture. The poet depicts the way these rulers function; they curve and twist like a snake. Their administration follows the serpentine course, thus making it difficult for the ruled to understand the way the country is being run. Manipulation, vacuous rhetoric, lying and deception become their stock in trade: "These leaders today/Serpents of different kinds in strange/Political garments which they shed/As gains come and go" (p. 10). This particular line underscores in strong terms the callous nature of Cameroonian neocolonial leadership.

The snake image is a dense symbol with metaphoric possibilities. The snake sheds its skin which 
symbolically is a regenerative process, but within the context of this poem this regeneration has negative undertones as the poet bemoans:

\section{Never trust a serpent,}

A tempter never straight in its ways:

At rest it is coiled

At work spiraled

This sly looks shy

Yet strike (p. 10).

In biblical history, the ancient snake is responsible for the demise of humankind as it tempted Eve and Adam in the Garden of Eden so that current problems stem from there. Besides, the bite of a snake is deadly and poisonous. The poem is a lampoon of the leaders' misrule, their cunning and hypocritical behavior: "Preying on all alike/Feeding and hurting in mock humility/This hypocrite lays pretending humility/Like all traitors, waiting to sell its cause" (p. 10). This hypocritical and pretentious behavior of these leaders is compounded by their corrupt practices: "This traitor thrives/On cheap and corrupt ways" (p. 10). The speaker's imagination deftly shifts between the lives of the oppressors and the oppressed, the nation and its surroundings, the particular and the general, the local and the allegorical thereby bringing the concepts of power and marginality.

The alliteration "This sly looks shy" is telling; the Cameroonian politician is a sly who pretends to be shy when making vacuous promises. Also, snakes hiss, using "s", so the line mirrors the sound. He thrives on deception and lies-telling. His plan is to barter the nation's interest for his personal gains. "Never trust a serpent/A tempter never straight in its ways" (p. 10).

In manner and temperament, Alembong in "The Sin of Glory" and "The Democrats and His Fans" expresses the same social consciousness and sentiments. The poet indicates that poetry cannot be divorced from social obligation, and the conscientisation of the ruled is one of these obligations. These two poems like those of Doh are an assertion of the will of the Cameroonian people to achieve their dreams. "The Sin of Glory" recounts an unpleasant political scene where the politician uses vacuous rhetoric to cajole and hoodwink the cynical masses. The poet blames both the Cameroonian politician and the ignorant masses: "He mounted the rostrum/Fist clenched, and the punched air/Received his loud promises" (p. 21).

The clenched fist symbolizes the greedy and stingy nature of this particular politician who wants the people's votes, yet is not willing to alleviate their condition and fulfill his promises. The politician's eccentricity and callousness are motifs that take centre stage in the poetic cosmic and consciousness of the poetic vision of Doh and Alembong. Having deceived the population and left them wretched, the evidence of the acquisition of material wealth is manifest on his shapeless body. This is an indication that ill-gotten wealth has a devastating effect on one's physiology.

With conquered votes in hand 
His stomach began to fall over his belt

While their hearts were being sucked dry

Of the last drop of hope (p. 21).

Poetry is relevant only if what the poet utters touches the reader and effects a response, be it in the form of laughter, amusement, weeping or simply reflection. The shapeless and bloated stomach of this politician is a demonstration of what ill-gotten wealth can do. Though this symbol evokes laugher, it also brings out the disadvantage of illicit acquired wealth. There are legitimate grounds for rejecting the material prosperity and spiritual bankruptcy of the comprador bourgeoisie. While this politician swims in the cesspool of ill-gotten wealth, the masses who have legitimized his stay in power are being, “...sucked dry/Of the last drop of hope" (p. 21).

In "The Sin of Glory", the poet demonstrates that the acquisition of a new consciousness and a rejection of the old is the only survival strategy that the oppressed masses must adopt. In other words, a people need education in order to achieve liberty, freedom and democracy, and the poetry of Doh and Alembong are just playing that function.

The theme of the betrayal of independence is once more articulated in "The Democrats and His Fans". The poem is an expose on what politicians go through to acquire powers; first they consult dibias/sorcerers at night; secondly thugs are hired in the day to brutalize their opponents; but frustration comes in when more political parties crop up to compound and complicate an already complex situation. But after all this, he loses elections. Hear the poet/persona:

Like spirit-maidens

he danced at noon

on the threshold of pain.

Caught in mid-throb limping,

unable to get the rhythm right,

he settled on his own urine (p. 19).

The poet compares this politician to spirit-maidens because politics in contemporary Africa has transcended the physical as it is sustained by metaphysical forces. The poet underscores the fact that it is the obsession with power that has led African politician find himself in this painful and bizarre act as he ends up settling "on his own urine". Urine here symbolizes his demise and failure in politics. This tragic experience exemplifies the fact that uneasy consciences are caught in their own contradictions.

Not satisfied with powers acquired from native doctors, thugs are hired to brutalize their opponents: "With warm clothing from across the seas/and paid gun-men at vantage points/came the time for harvest reports" (p. 19). But the harvest reports are a disaster because the formations of other political parties sponsored by western imperialists have also come to the scene to create confusion and impoverish indigenous political parties:

And licenses came from across the seas 
to enable the mole deepen our debt-wells

and stamp more wrinkle on our faces.

And more tentacles came from across the seas

to enable the octopus pluck us from up-stream dwellings

and add more skulls to the home of death (p. 19).

The mole that deepens the debt-wells symbolizes those parties which are sponsored by imperialists for their own gains. The poet/persona laments that since indigenous parties do not have the wherewithal, this puts them in a financial mess. Besides symbolism and comparison, the poet uses a repetition and a rhetorical question in which when combined produce a cumulative effect and also convey a forceful image. The rhetorical question is couched in animal images that bespeak the vicious cycle of human bestiality that characterizes Cameroonian/African contemporary politics: "But why keep the hawk and reject the dove/When one day of rain is better than/One thousand days of drought?” (p. 20).

The images/metaphors of the hawk and dove are focal and fundamental in this poem. The hawk is the symbol of the destruction that Capitalism encompasses and encapsulates; it is a bird that preys on other birds. It also refers to a person who supports the use of force in political relationships. The dove on the other hand is a metaphorical symbol of peace. Again drought in African literature symbolizes suffering, pains and frustration. It symbolizes the emptiness, meaninglessness and nothingness of life.

From the cultural materialist point of view poetry is real poetry when it throbs with the rhythm of the real world in which benign forces are struggling against malignant forces to make the world better. This is one of the fortes of the philosophy of dialectics. Within this framework, the hawk and the dove are dialectically opposed. Thus cultural and dialectical materialism which explain the development of the world as dialectical is hard to understand unless we take into consideration that it implies a certain dynamism from a lower to a higher stage. This dynamism is anchored in the images of the hawk and the dove, the dove which is a metaphor of peace being the higher level of development. Such a symbolic premise suggests a hermeneutic form, which recognizes and opens the dialectic between the force of the rulers and the peaceful nature of the ruled which present the historical actuality this poetry fictionalizes.

The poem is structured into eleven stanzas different in relationship of the ideal to reality. The first nine stanzas concern with memory and the ordeal politicians go through in their attempt to acquire power; the last two stanzas conclude in question form by proffering the alternatives of existence. The lines "... one day of rain is better than/one thousand days of drought" (p. 20), are repeated to bring out this higher level of consciousness.

The poem closes with images which assure the reader with a better future if the dove/peace is embraced and not the hawk/force.

The two poets also explore the possibilities of a culture of dialogue within the framework of the aesthetic of opposition and anti dialogism as underscored in this paper. In other word, it attempts a 
synthesis of dialectics and dialogic which provide socio-political development in the Cameroonian society. This is the preoccupation of the final part of this paper.

\section{Toward a Culture of Dialogue}

Bakhtin's idea of dialogicity is always the subject of "an address" because one cannot talk about himself but can only address oneself to another person (Guerin et al., 1992, p. 302). One cannot understand another person as an object of neutral analysis or master him through a merging with him by empathizing with the person. The two should see each other as persons and subject of history. The solution is that dialogue is not the threshold to action, but it is action itself. Life is meaningless without dialogue. Alan Sinfield in "Cultural Materialism, Othello, and the Politics of Plausibility" clarifies this: "Meaning, communication, language work only because they are shared. If you invent your own language, no one else will understand you; if you persist, you will be thought mad (Julie \& Michael, 2004, p. 743). The relation between violence and the ideological power of the state may be glimpsed in the way the ruling elites try to manipulate the consciousness of the masses. This is the point expressed in the poetic imagination of Alembong and Doh.

The two poets as the people's representatives make their people subject of history and not object of history. They want to create a situation where neither the oppressors nor the oppressed are oppressed. On this issue of culture of dialogue, Paulo Freire contends that the commitment of the revolutionary leaders to the oppressed is at the same time a commitment to freedom. And because of that commitment, "the leaders cannot attempt to conquer the oppressed, but must achieve their adherence to liberation... Authentic adherence is the free coincidence of choices; it cannot occur apart from communication among people, mediated by reality" (1970, p. 149).

The two poets in many of their poems proffer dialogue and sustainable peace as the way forward. To them only dialogue can bring about a harmonious society where human rights are respected. This idealistic situation will bring about love and the respect for the inalienable rights of both the oppressed and oppressors. This particular motif is well articulated in Doh's "On Familiarity and Contempt" and Alembong's "The Celebration".

Doh's "On Familiarity and Contempt" paints a picture of cooperation and communion between the rulers and the ruled. Hear the poet:

The journey yet was to begin

He thought he had arrived

That nobles may not for long

With serfs and farm hand belong

Fooled by such proximity in bed

The shoulder above the head

Tries to soar 
To find its efforts unproductive (p. 51).

In a situation where the nobles and the serfs interact freely, the efforts of the oppressor to oppress are unproductive. Everyone is a subject and none is an object. Although one subject may initiate a political blueprint for the way forward, the others must also be subjects of this act: they must believe that the people are capable of participating in the pursuit of their own liberation, welfare and governance. Doh's "On Familiarity and Contempt" which attains a lyrical quality through the use of devices such as biblical allusion, animal imagery, simile, horticultural images and rhyme scheme as we find in the two stanzas constitute a powerful expression of hope and faith of genuine cooperation and synthesis of the two dialectical world-views. For example, the aabb rhyme scheme indicates a move toward this culture of dialogue and cooperation which Doh attempts to proffer in this particular poem. Readers are given the impression of a circle of friends who come together for mutual benefits, and this mode of existence according to the poet/persona should be alive in speech, rhythm, emotion and thought because this was God's intention: "To him heaven he had humbled/And so over all lorded it/Even God meant not a bit/To this bloated maggot" (p. 51).

The "h" alliteration in the first line emphasizes and reinforces this new dispensation of cooperation and communion. This particular poem encapsulates and encompasses Doh's social vision. In this new dispensation, hypocrisy has no place: "For only a while can hypocrisy reign/As the truth even from the skies will rain" (p. 51).

Alembong articulates the same motif in "The Celebration". Here the dominant imagery that is exploited and explored by the poet is animal imagery representing human beings. Even animals of prey no longer prey on their victims. The camaraderie that reigns in this animal kingdom symbolizes the type of society the poet recommends for his own society. If animals can live in such harmonious and friendly society, human beings can do better than this; the poet seems to be saying: "Eagles and hyenas screamed in joy/And the robin and sparrow chirped in approval/As the pig was carted in by the horse/To head the farm" (p. 70).

The awareness of the co-existence of two ways of life and peace within one social stratum is once more echoed in the lines below:

Ants filed pass, millipede too,

Grasshoppers hopped pass, wrens too,

Frogs leaped pass, rabbits too,

Serpents glided pass, seagulls too,

Owls flitted pass, parrots too,

And asses jogged pass and cats stole pass

As the pig grunted repeatedly in approval (p. 70).

Apart from the musicality created by the repetition of the word "too" at the end of the first four lines of this stanza, this device also emphasizes the freedom that characterizes this culture of dialogue. This 
particular poem brings out the feeling of openness, self-consciousness and freedom that the culture of dialogue incarnates. There are no victims and victors or victors and vanquished; everyone is a victor and a free born. "The Celebration" is a poem to the reader which suggests more than it says, offering an aesthetic for the poem as well as a way of life to the Cameroonian/African people. Alembong insinuates that animals live a better life than human beings. This is because in the human kingdom, the class which is the ruling material force is, at the same time its ruling intellectual force and this very class which has the means of material production at its disposal has control at the same time over the means of mental production. The lumpen proletariat class is considered as object that can be used and discarded. Alembong like Doh calls for mutual co-existence between the rulers and the ruled, and this is plausible if the culture of dialogue is instituted in the Cameroonian society.

\section{Conclusion}

In conclusion, it could be said that Emmanuel Doh and Nol Alembong's poetry is a response to the socio-political and economic realities that overwhelm the Cameroonian society which is caused by the abuse of power. In proposing dialogue as a panacea to this socio-political sclerosis, the poets think that sustainable peace can be attained in the Cameroonian society.

One of the major contentions of this paper is that, as a means of communion and cooperation between poet and people, poetry has the advantages of both breaking down the barrier between reason and emotion and obliterating the distinction between classes. More often Doh and Alembong draw from the biblical quarry to convey their ideological standpoints of peace, liberty and freedom.Using the new historicist critical theory and the concept of socialist realism to interpret, analyze and evaluate Doh's Not Yet Damascus and Alembong's Forest Echoes, this paper concludes that Doh and Alembong's poetic orientation is a response to the socio-political problems overwhelming the Cameroonian society. In this regard this paper proposes dialogue as a socio-political therapy to this malaise.

\section{Acknowledgements}

I am indebted to the Ministry of Higher Education in Cameroon for introducing in 2009 the Modernization Research Allowance in Cameroonian State universities which has boosted and revamped research in Cameroon state universities. I am also grateful to the research allowance paid by the Faculty of Arts, University of Buea for research related activities.

\section{References}

Alembong, Nol. (2010, February 8). Personal Communication. Interview by Andrew T. Ngeh. Alembong, Nol. (2012). Forest Echoes. Yaoundé: Miraclaire Publishing LLC. Amuta, Chidi. (1989). The Theory of African Literature: Implications for Practical Criticism. London: Heinemann. 
Bakhtin, M. M. (1989). Discourse in Life and Discourse in Art (Concerning Sociological Poetics). In R. C. Davies, \& R. Schleifer (Eds.), Contemporary Literary Criticism: Literary and Cultural Studies. New York: Longman.

Barry, P. (1995). BeginningTheory. Manchester: Manchester University Press.

Doh, Emmanuel Fru. (2007). Not Yet Damascus. Bamenda: Laangaa Research Publishing CIG.

Dollimore, J., \& Sinfield, A. (Eds.). (1994). Political Shakespeare: New Essays in Cultural Materialism. Manchester: Manchester University Press.

Fokkema, D., \& Ibsch, E. (1995). Theories of Literature in the Twentieth Century. London: ST Martin Press.

Freire, P. (1970). Pedagogy of the oppressed. New York: The Continuum Publishing Company.

Guerin, W. et al. (1992). A Handbook of Critical Approaches to Literature. New York: Oxford University Press.

Holderness, G. (1988). The Shakespeare Myth. London: Manchester University Press.

Language and Commitment in Anglophone Cameroonian Poetry: The Poetic Vision of Three Anglophone Cameroonian Poets. (2013). South African Journal of African Languages (SAJAL), 107-114.

Lippmann, W. (1991). A Preface to Morals. London: Macmillan Publishing Company.

Little, W. F. H. W. (1961). The Oxford Universal Dictionary. London: Clarendon Press.

Lukacs, G. (1963). The Meaning of Contemporary Realism. London: Merlin Press Ltd.

Murfin, R., \& Ray, S. M. (1979). The Bedford Glossary of Critical and Literary Terms. Boston: Bedford.

Ngara, E. (1990). Ideology and Form in African Poetry. London: Heinemann.

Ngeh, A. (2012). Socialist Realism and the Dialectics of Violence in Anglophone Cameroonian Drama: Bate Besong and Bole Butake's Dramatic Vision. In L. Krishhan et al. (Eds.), Creative Forum. New Dehli.

Ngeh, A. T., \& Usman, S. (2014). Power Dialectics and the Crisis of Identity in Anglophone Cameroonian Poetry: The Poetic Vision of Gahlia Gwangwa'a and Bate Besong. http://dx.doi.org/10.5296/jsss.v2il.5988

Ollman, B. A. (1980). Marx's Conception of Man in Capitalist Society. London: Cambridge University Press.

Rivkin, J., \& Ryan, M. (Eds.). (2004). Literary Theory and Anthology. Malden: Blackwell Publishing.

Takem, J. T. (1990). Theatre and nationalism in Nigeria: A Dialectical Comparative Discourse on Hubert Ogunde and Femi Osofisan. MA Dissertation submitted to the University of Jos, Plateau State, Nigeria.

The Holy Bible. (1978). New International Version Containing the Old and New Testaments. 